\title{
The Use of Mobile Learning to Improve Students' Cognitive Development
}

\author{
Leni Pebriantika ${ }^{1}$, Oktariyana $^{2}$, Aminah $^{3}$, Henni Kusumastuti $^{4}$, Otto Fajarianto ${ }^{5}$ \\ \{lenikabisat@gmail.com, okta14unulampung@gmail.com, amimhdp@gmail.com, \\ henniksa65@gmail.com,ofajarianto@gmail.com\} \\ Education Technology Program, Baturaja University, Sumatera Selatan, Indonesia ${ }^{1}$, Health and \\ Creation Physical Education Program, Nahdlatul University Ulama, Lampung, Indonesia ${ }^{2}$, Primary \\ Teacher Education Program, Universitas Almuslim, Aceh, Indonesia ${ }^{3}$, State Administration \\ Program, Sang Bumi Ruwa Jurai University, Lampung, Indonesia ${ }^{4}$, Universitas Swadaya Gunung \\ Jati, Indonesia ${ }^{5}$
}

\begin{abstract}
The rapid development of technology and science has led to the development of the education world today. One effort to improve education and learning quality is inseparable from the role of educators in implementing appropriate and efficient learning media that can support learning to improve students' cognitive development. One of the media that can be used is to utilize mobile learning applications. M-learning can make learning different because teachers and students can access learning, direction and applications related to learning wherever and whenever. It will make the learning process more interesting, increase attention to the material. The purpose of the research was to develop a mobile learning application to improve students' cognitive development. The research method was used namely Research \& Development using ADDIE (Analysis, Design, Development, Implementation, and Evaluation) models. The results of this study indicated that mobile learning could improve students' cognitive development.
\end{abstract}

Keywords: mobile learning, cognitive development, students

\section{Introduction}

Education is a conscious effort and aims to develop human qualities. As an activity that is aware of the objectives, the implementation of education is in a continuous process in every type and level of education. One part of the effort to improve education and quality of learning is inseparable from the role of the teacher in using strategies, methods, and means in delivering material in learning. Lecturers can also use media that can support learning for students' cognitive development.

Cognitive development of students has an impact on increasing student learning outcomes. The problem of the low learning outcomes of students in this course has a negative impact, given the importance of this course for a prospective educator. Learning outcomes are closely related to the learning process in the classroom. If there are problems in learning outcomes, it can be estimated that several influencing factors are internal factors and external factors. Internal factors are the ability of students to understand the concepts of Student Development, motivation, and attitudes toward Student Development courses. While the external factor is the ability of the lecturer to deliver and facilitate the learning process, the supporting facilities for the learning 
process, the time allocation prepared by the study program and the supporting media of the learning process. Hyo Jung Kim (2017) said that learning with mobile learning is a learning approach that is very flexible because the interaction and communication between students and lecturers can occur based on the level and needs of individual learning based on the needs of students [1]. Kalkuse (2015) explained that students must be able to be involved in educational activities without the limitations of time and place [2].

The possibility that appears above shows that the stronger the demand to create an innovation or a renewal regarding learning that can provide alternatives for solving learning problems. A lecturer is deemed necessary to always improve the quality of self in professionalism, expertise, and media that support the learning process.

Mobile learning is a learning model that utilizes information and communication technology. In the learning concept, mobile learning brings the benefits of the availability of teaching materials that can be accessed at all times and visualization of interesting material. The constructivism learning environment imposes a new role for lecturers. Lecturers as facilitators for students who will motivate students to achieve and hone skills. Directing how students learn concepts both inside and outside the classroom. Mobile learning can overcome teacher problems regarding time management and increase student independence to understand learning material [3].

The presence of mobile learning is intended as a complement to learning and provides opportunities for students to learn material that is poorly understood whenever and wherever [4]. Mobile learning can improve students' skills [5]. Mobile learning influences improving students' academic achievement. According to Idris Gosku (2013: 6) "In our modern life, it is possible to outline the mobile devices used in mobile learning as the following: a) Laptops; b) Tablet PC; c) PDA (Personal Digital Assistant d) Smart Phone "[3]. In modern life, several devices can support mobile learning including laptops, tablet PCs, PDAs, and smartphones. From the research data conducted by Ken Nee Chee (2017: 12) smartphone is the most widely used device in mobile learning [4].

\section{Method}

The research method was used in this study namely Research \& Development. The approach taken was mix methods research which combines qualitative and quantitative methods. It was done to process all data and information, thus a comprehensive explanation can be obtained. The development model was applied namely ADDIE Model with stages, namely Analysis, Design, Development, Implementation, and Evaluation.

\section{Analysis Phase (Analysis)}

At this stage, data and information are collected through direct observation in the field. At this stage also, initial needs analysts such as student analysis, technology analysis, and literature study are carried out, especially those related to the concept of mobile learning to improve students' cognitive development.

\section{Design Stage (Design)}

The design phase in mobile learning to improve the cognitive development of students produces flowchart and storyboard. Storyboard design includes layout/layout, coloring, and 
text. The layout is the layout of each item which is essential to communicate the intent or purpose of each screen.

\section{Development Stage}

This development stage is a continuation of the design that translates flowchart and storyboard into a product, in this study in the form of mobile learning applications to improve students' cognitive development.

At this stage, expert validation is carried out before the product is feasible to be implemented.

\section{Implementation Stage}

At this stage, it is an implementation of a product that has been declared feasible to use. To see the results become better, it is done in several stages:

a. One - One Trial (One to One)

One-on-one trials were carried out together with expert evaluations. This evaluation is carried out to measure the level of practicality of the product being developed. At the time of testing 3 students were chosen who had different levels of ability (low, medium, and high).

b. Small Group Test (small group try-out)

Small group trials were carried out on 10-20 students. At this stage, the same stage is carried out with one to one. But the difference is that the instrument used is a questionnaire, while the evaluation of one to one uses an interview instrument.

c. Field Try-out

Large group trials are field trials that are equivalent to the target or the number of actual students as a whole. At this stage, this is done to get comprehensive information about the quality and effectiveness of mobile learning to improve students' cognitive development.

\section{Evaluation Stage}

At this stage, summative evaluation is carried out, this is done to determine the effectiveness of the product on the learning outcomes of students by giving students the pretest and posttest.

These stages can be seen as in the following chart: 
Stages of the Research Process

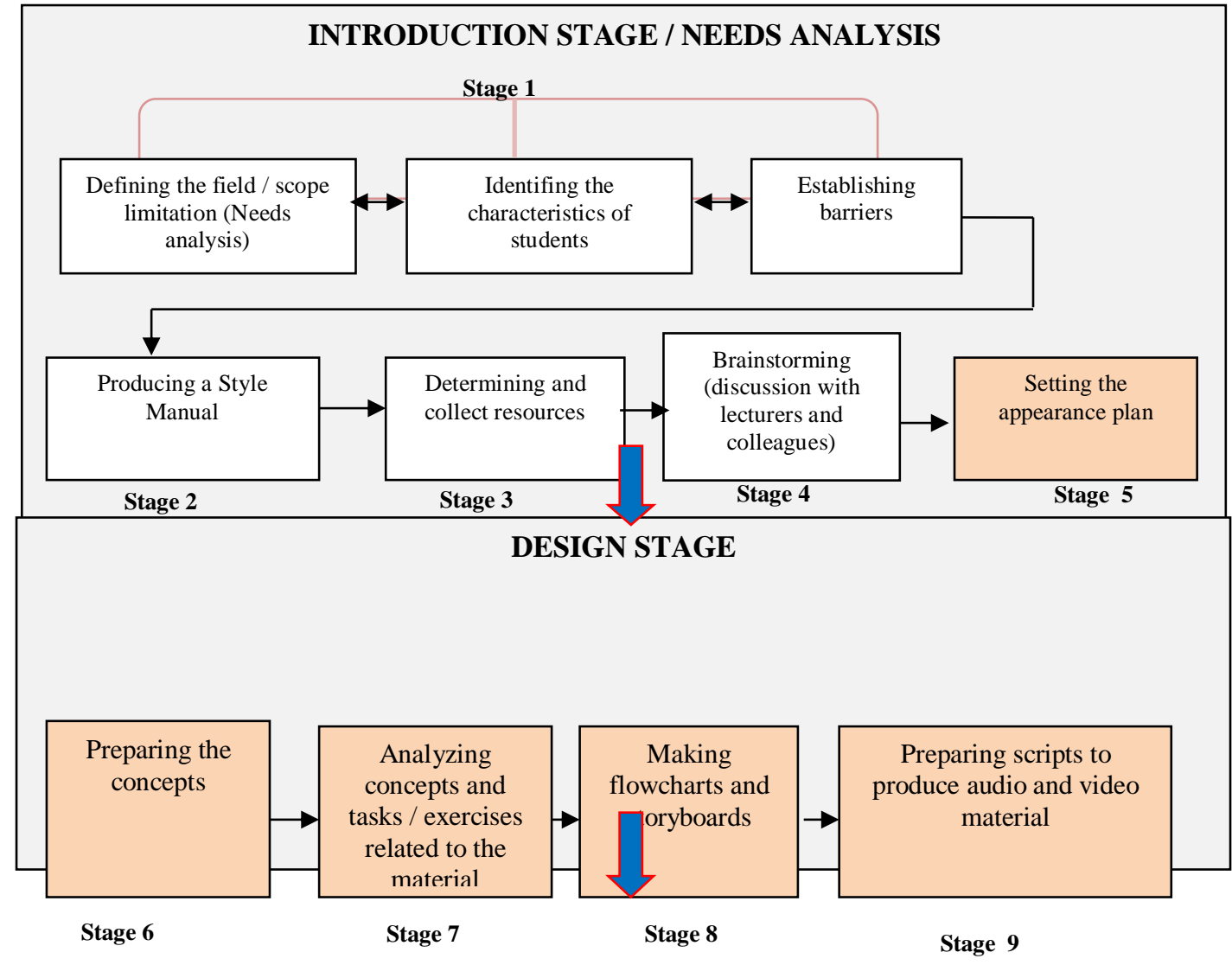

DEVELOPMENT, IMPLEMENTATION, AND EVALUATION STAGES

Stage 10

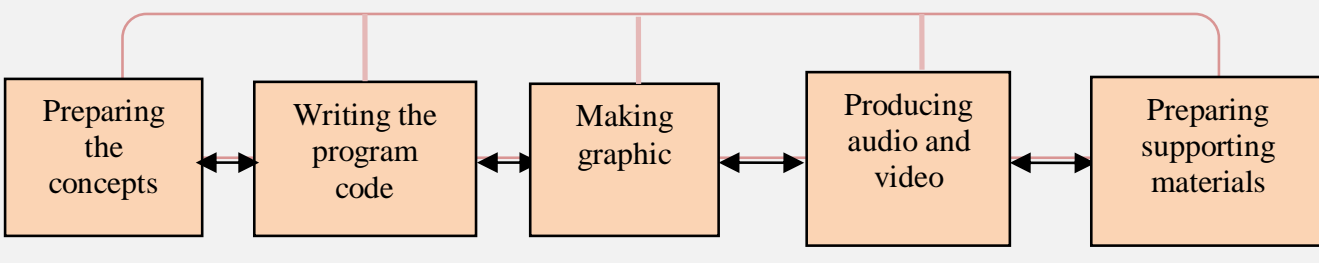

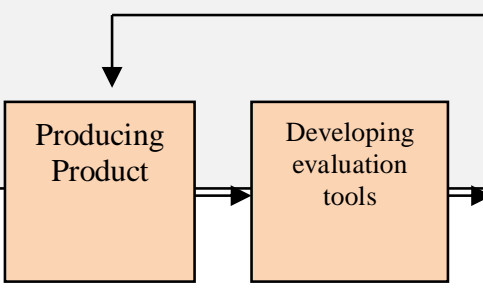

Stage 11

Stage 12

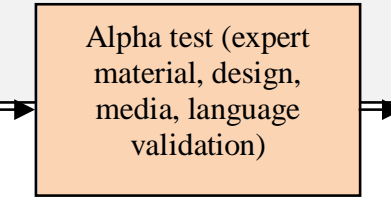

Stage 13

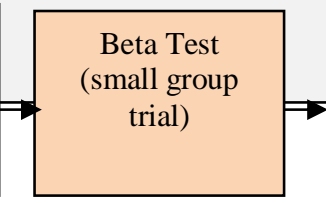

Stage 14
Field test

(field trial)$$
\text { . }
$$

Stage 15

Figure 1 Research Stage 
Data analysis techniques to calculate the percentage of each instrument with a formula that refers to the opinion of Sudijono (2011) as follows:

Information :

$$
p=\frac{\mathbf{f}}{\mathrm{N}} x 100 \%
$$

p: percentage number

$\mathrm{f}$ : the frequency that is being sought

$\mathrm{N}$ : Number of Cases (number of frequencies)

Then the results are adjusted to the criteria presented by Arikunto (2010) as follows:

Table 1 Scale of Persentage Interval

\begin{tabular}{|c|c|c|c|}
\hline \multirow{2}{*}{ Percentage interval } & \multicolumn{2}{|c|}{ Value of Four Scale Changes } & \multirow{2}{*}{ Explanation } \\
\cline { 2 - 3 } & $\mathbf{0}-\mathbf{4}$ & $\mathbf{D}-\mathbf{A}$ & \\
\hline $86-100$ & 4 & $\mathrm{~A}$ & Very good \\
\hline $76-95$ & 3 & $\mathrm{~B}$ & Good \\
\hline $56-75$ & 2 & $\mathrm{C}$ & Enough \\
\hline $10-55$ & 1 & $\mathrm{D}$ & Poor \\
\hline
\end{tabular}

Source:Arikunto, 2010

\section{Result and Discussions}

From the processing of data obtained from the validators and trial subjects, by referring to data analysis techniques in the predetermined results, the results of the analysis of each validator and the trial subjects were obtained. Based on the results of the validation test from media experts, the percentage of values was $87.5 \%$ with a good predicate. And the percentage of the results of the material expert validation test obtained the overall percentage was $80.26 \%$ with a good predicate. Thus, from the media side and the material produced is categorized as good or valid.

From the data analysis of individual scale trials, with the object of research as respondents, 3 students with an average percentage of all aspects of the mobile learning application was $85.48 \%$ with a good predicate. Furthermore, the researcher did was stage III, which was to test small-scale products with respondents of 10 students with an average percentage of all aspects of the mobile learning application was 86.27 with the very good predicate. Then, the researcher did stage IV, which was to test large-scale products with 105 respondents with an average percentage of all aspects of learning with mobile learning was $86.41 \%$ with a very good predicate. As a whole, it can be concluded that the product has an excellent level of feasibility and can improve the cognitive development of students. 


\section{Conclusion}

This study produced a product in the form of a mobile learning application to improve students' cognitive development. The development model used is the ADDIE model. From the implementation of the field, the results of the overall aspects of Learning with mobile learning are $86.41 \%$ with the very good predicate. Thus, as a whole can be concluded that the product has a level of feasibility that is very good and able to improve the cognitive development of students.

\section{References}

[1] Kim, Jung Hyo., Lee, Jin Myong., Rha, Jong Youn Rha. 2017. "Understanding the role of user resistance on mobile learning usage among university students". Computer\& Education, dx.doi.org/10.1016/j.compedu. 2017.05.015

[2] Kulkuske dan Hulme, Agnes. 2015. Mobile Learning A Handbook For Educator and Trainers. London: Routledge.

[3] Goksu, Idris dan Atici, Bunyamin. 2013. "Need For Mobile Learning: Technologies and Opportunities". $13^{\text {th }}$ International Educational Technology Conference. doi : 10.1016/j.sbspro. 2013.10.388.

[4] Chee Nee, Ken., Noraffandy Y., Nor Hasniza Ibrahim dan Mohamed Noor.2017. " Review of Mobile Learning Trends 2010-2015: A Meta-Analysis". Journal of Educational Technology $\&$ Society. ISSN 1436-4522 (online)

[5] Winataputra, U. S. 2008. Teori Belajar dan Pembelajaran. Jakarta: Universitas Terbuka.

[6] Gredler, Margaret. 2009. Learning and Instruction: Theory into Practice. New Jersey: Pearson Education.

[7] Schunk, Dale H. 2012.Learning Theories:An Educational Perspective. Edisi ke enam. Penterjemah Eva Hamdiah, Rahmat Fajar. Yogyakarta: Pustaka Pelajar.

[8] Rahmelina, Liranti. 2017. " Perancanga mobile learning berbasis android pada mata kuliah sistem operasi di STIMIK Indonesia Padang”, Jurnal Informatika Vol. 11, No.2 Juli 2017.

[9] Maribe, Robert B. 2009. Instructional Design: The ADDIE Approach. New York: Springer 